\title{
RAMP2 wt Allele
}

National Cancer Institute

\section{Source}

National Cancer Institute. RAMP2 wt Allele. NCI Thesaurus. Code C127151.

Human RAMP2 wild-type allele is located within $17 q 12-q 21.1$ and is approximately $5 \mathrm{~kb}$ in length. This allele, which encodes receptor activity-modifying protein 2 , plays a role in the regulation of calcitonin gene-related peptide type 1 receptor activity. 